\title{
A Field Test of All-Weather Surfaces for Horse Paddocks
}

\author{
Hans E. von Wachenfelt \\ Department of Biosystems and Technology, Swedish University of Agricultural Sciences, Alnarp, SE 230 53, Sweden
}

\begin{abstract}
This field study sought to determine the all-weather surface construction providing the least contaminated runoff and drainage effluent when exposed to moderate to heavy precipitation and different manure loads in horse paddocks during wintertime. Two different combinations of non-woven and woven geotextile together with two gravel fractions of 200 mm were exposed to precipitation and horse manure/urine for two years under two manure regimes (manure removal and manure accumulation). In a simulated rainfall (SR) study, the test areas were also exposed to $50 \mathrm{~mm}$ precipitation for $30 \mathrm{~min}$ and $15 \mathrm{~kg}$ of horse manure under the two manure regimes. Runoff, drainage effluent and leachate flow were measured and sampled for both regimes. The geotextile-gravel construction reduced runoff and drained the test area throughout the two-year period, confirming construction stability and a dry walking surface area at a mean drain flow of $3.65 \mathrm{~L} \mathrm{~m}^{-2} \mathrm{~h}^{-1}$. The concentrations of total $\mathrm{N}$, total phosphorus (TP), chemical oxygen demand (COD) and total solids (TS) in fluids leaving the test areas in winter were lower than in previous studies, due to lower horse density. The mean drainage concentration of TP, COD and TS was 3.4, 231, $739 \mathrm{mg} \mathrm{L}^{-1}$, respectively, due to manure removal in the SR study. The TP $\left(1.9 \mathrm{mg} \mathrm{L}^{-1}\right)$ concentration in drain fluids was reduced by $47 \%$ in the test area consisting of a single geotextile compared with previously reported values $\left(3.6 \mathrm{mg} \mathrm{L}^{-1}\right)$. With the paddock designs tested here, non-point pollution from paddocks could be controlled and reduced.
\end{abstract}

Key words: Geotextile, horse, manure, runoff, drain, leachate.

\section{Introduction}

\subsection{Background}

To get their daily exercise and stay in good condition during the winter season, horses have to rely on paddock all-weather surface constructions, such as drained gravel areas, or concrete and asphalt as solid, non-permeable areas. However, these non-permeable areas are expensive and promote runoff compared with permeable surfaces [1]. There are currently no Swedish restrictions on horse density and the use of outdoor feeding places in paddocks. This could result in concentration and accumulation of nutrients in the ground because of high animal density or because no uptake of nutrients occurs through pasture [2]. In winter time, runoff readily occurs and runoff sediment could pose a risk of phosphorus (P) pollution in nearby watersheds [2].

\subsection{Sources of Non-Point Pollution}

In recent years, scientific research has concluded

Corresponding author: Hans E. von Wachenfelt, Ph.D., research fields: farm building design and environment. that $\mathrm{N}$ and $\mathrm{P}$ runoff and leaching from horse paddocks can have a large impact on the eutrophication problems in water catchment areas, mainly through unremoved feed remnants and faeces, which can result in nutrient build-up in the soil [3-6].

Horse pasture or paddocks receive significant amounts of $\mathrm{P}$ and $\mathrm{N}$ through manure and urine, through horses spending at least 8-12 h per day on pasture, with supplementary feed in winter time [7, 8]. However, few studies have examined $\mathrm{P}$ leaching from horse pastures, despite the fact that horse manure contains more $\mathrm{P}$ than manure from cattle [7].

In a study of nutrient leaching from horse paddocks on clay soils with supplementary feeding, Parvage [2] found that $\mathrm{P}$ could pose an environmental hazard to nearby watersheds if the density of horses on the pasture exceeded 2.5 animal units per hectare.

Although horses have become increasingly numerous in Europe in recent decades and pasture and paddocks for horses currently occupy approx. 4\% of total European agricultural land [9], guidelines on horse keeping are not included in the EU Water 
Framework Directive [10].

\subsection{Geotextile Constructions}

Geotextile-gravel constructions have been a cost-effective way of producing all-weather surface for animals in outdoor production since 1990. The construction enables a decreased depth of construction [11, 12], improves the load bearing capacity and stability of the surface and promotes drainage and infiltration.

Geotextile filtering characteristics studies indicate that small pore opening size exposed to cattle slurry could have a sealing effect towards the underlying soil [13, 14], which could prevent nutrient leaching and deposition into underlying soil and groundwater pollution [15].

In two earlier studies on cattle manure the objective was to identify the geotextile-gravel construction, with a reduced construction depth of $200 \mathrm{~mm}$, that generated the least contaminated runoff and leachate flow [16] and the least contaminated runoff, drain and leachate flow [15] during manure application and rainfall. The objective of the present two-year field study was to confirm the results from that study by von Wachenfelt [15] for horse manure. This paper presents an evaluation of a similar configuration, this time with horses, to establish that the performance can be effectively replicated.

\subsection{Aims and Objectives}

The overall aim of this study was to identify the geotextile-gravel construction resulting in the least contaminated runoff and drainage effluent when exposed to moderate to heavy precipitation and different manure loads in horse paddocks during wintertime.

Specific objectives were to determine whether a geotextile-gravel construction in practice gives an acceptably stable surface for horses, runoff control, reduction of nutrients in the fluids leaving the test area and sealing towards the underlying soil surface instead of a membrane, and to investigate whether regular manure removal has an effect on runoff and drainage effluent quality.

The hypothesis was that a $200 \mathrm{~mm}$ geotextile-gravel construction would provide a sufficiently stable surface pavement for horses, infiltration of runoff, high drainage efficiency and sealing towards the underlying soil surface instead of a membrane.

\section{Materials and Methods}

\subsection{Experimental Design}

Two field experiments were performed in two paddocks, with three test areas with different geotextile-gravel combinations in each paddock, located at Flyinge Horse Depot, Flyinge, Sweden. All plots had a geomembrane and $50 \mathrm{~mm}$ sand as a base (Fig. 1). Treatments following the procedures described by von Wachenfelt [15] were as follows (from bottom to surface):

(1) Combined treatment: Non-woven (Protexia FC 021), woven geotextile (Propex 6083), non-woven geotextile (Typar SF20), $150 \mathrm{~mm}$ gravel $(16 \mathrm{~mm})$ and $50 \mathrm{~mm}$ of gravel $(5 \mathrm{~mm})$;

(2) Single treatment: Woven geotextile (Propex 6063), $150 \mathrm{~mm}$ gravel $(16 \mathrm{~mm})$ and $50 \mathrm{~mm}$ of gravel (5 mm);

(3) Gravel treatment: $150 \mathrm{~mm}$ gravel $(16 \mathrm{~mm})$ and $50 \mathrm{~mm}$ gravel ( $5 \mathrm{~mm}$ ), control.

Both the Combined and the Single treatment consisted of a main strengthening geotextile (Propex 6083), while Typar SF20 and Protexia FC 021 only formed part of the Combined treatment. Typar is a non-woven filtering geotextile and was placed above the woven Propex 6083 geotextile to limit drain fluid TS concentration and promote oxygenation of organic nutrients. Protexia FC 021, also non-woven, a filtering geotextile with small pore opening size mounted on cuspated drainage, was placed under the Propex 6083 geotextile to minimise leachate to the underlying soil. The physical characteristics of the geotextiles are described in Ref. [15]. 


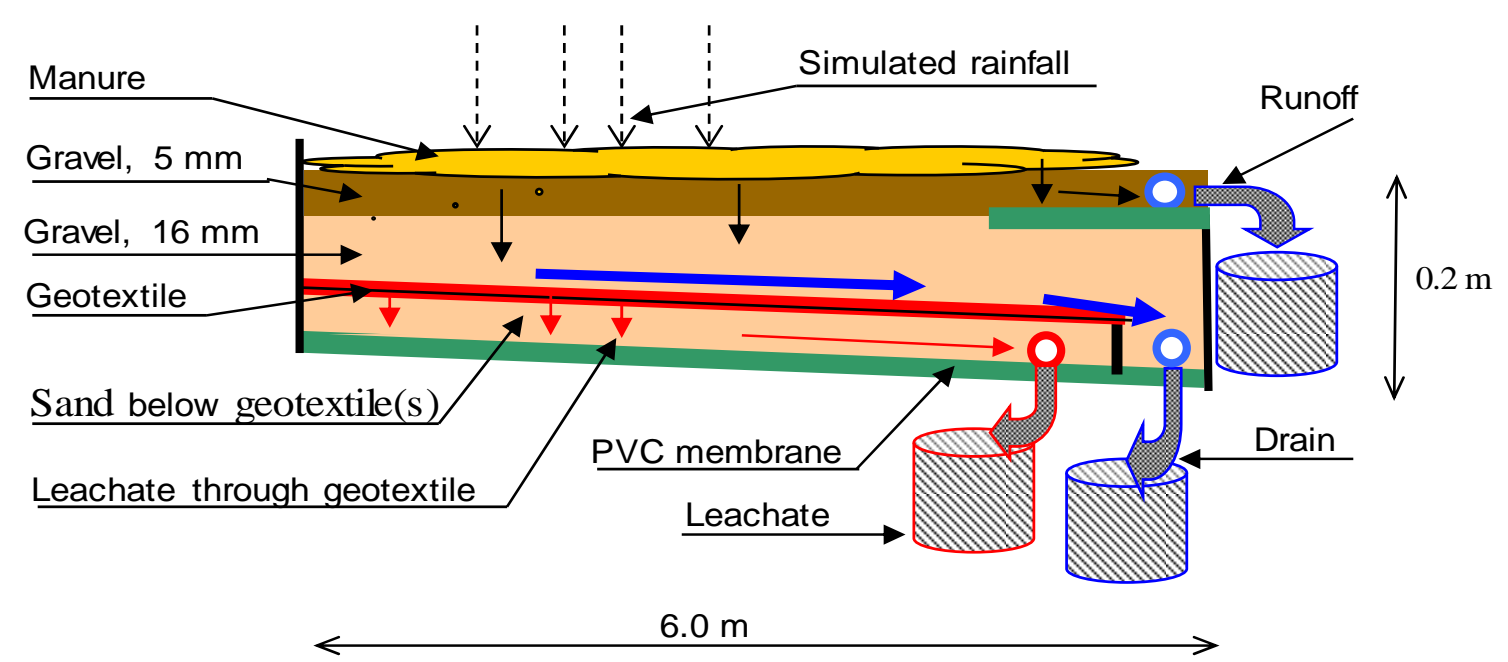

Fig. 1 Cross-section of the test area construction, where the geotextile treatments consisted of a "Single" geotextile, or a “Combination" of three geotextiles, or only “Gravel” (no geotextile).

Table 1 Composition of horse manure ( $n=4$ per sample).

\begin{tabular}{|c|c|c|c|c|c|c|c|c|c|}
\hline Experiment & Sample & $\begin{array}{l}\mathrm{TN}^{1} \\
\mathrm{mg} \mathrm{kg}^{-1}\end{array}$ & $\begin{array}{l}\text { TAN }^{2} \\
\text { mg kg }^{-1}\end{array}$ & $\begin{array}{l}\text { TAN }^{2} \\
\% \text { TS }\end{array}$ & $\begin{array}{l}\mathrm{NO}_{3}-\mathrm{N}^{3} \\
\mathrm{mg} \mathrm{kg}^{-1} \mathrm{TS}\end{array}$ & $\begin{array}{l}\mathrm{NO}_{2}-\mathrm{N}^{4} \\
\mathrm{mg} \mathrm{kg}^{-1} \mathrm{TS}\end{array}$ & $\begin{array}{l}\mathrm{TP}^{5} \\
\mathrm{mg} \mathrm{kg}^{-1} \mathrm{TS}\end{array}$ & $\begin{array}{l}\mathrm{COD}^{6} \\
\mathrm{mg} \mathrm{l}^{-1}\end{array}$ & $\begin{array}{l}\mathrm{TS}^{7} \\
\%\end{array}$ \\
\hline \multirow[t]{5}{*}{ Manure removal } & 1 & 3,000 & 335 & 0.17 & 12.9 & 5.7 & 4,600 & 235,000 & 20 \\
\hline & 2 & 3,850 & 360 & 0.15 & 10.4 & 4.2 & 3,800 & 275,000 & 24 \\
\hline & 3 & 4,350 & 540 & 0.20 & 9.4 & 2.3 & 3850 & 225,000 & 27 \\
\hline & 4 & 4,088 & 486 & 0.18 & 9.7 & 3.9 & 4,125 & 276,250 & 28 \\
\hline & 5 & 5,150 & 710 & 0.19 & 6.3 & 2.8 & 4,250 & 370,000 & 29 \\
\hline \multirow[t]{5}{*}{ Manure accumulation } & 6 & 4,600 & 395 & 0.15 & 8.8 & 2.8 & 3,700 & 260,000 & 28 \\
\hline & 7 & 4,150 & 415 & 0.16 & 9.2 & 5.1 & 4,750 & 305,000 & 27 \\
\hline & 8 & 4,250 & 470 & 0.18 & 6.6 & 0.3 & 3,900 & 385,000 & 27 \\
\hline & 9 & 3,000 & 300 & 0.14 & 12.4 & 0.2 & 6,100 & 175,000 & 22 \\
\hline & 10 & 3,350 & 595 & 0.28 & 11.9 & 0.6 & 5,800 & 240,000 & 21 \\
\hline
\end{tabular}

1-Totalnitrogen; 2—-total ammoniacal nitrogen; 3—nitrate nitrogen; 4—nitrite nitrogen; 5—total phosphorus; 6—chemical oxygen demand; 7—total solids.

The experiments were conducted in two separate time series, one during two winter seasons in 2013 and in 2014, the other as a simulated rainfall (SR) study.

In the first experiment in winter, manure (approximately $12 \mathrm{~kg}$ ) was deposited by horses and then manually removed after $24 \mathrm{~h}$ (manure removal). In the second experiment, approximately $70 \mathrm{~kg}$ of manure were allowed to accumulate on the test area surfaces for a week (manure accumulation).

In the SR test, the manure was applied at a rate of $15 \mathrm{~kg}$ per test area $\left(1.25 \mathrm{~kg} \mathrm{~m}^{-2}\right)$, simulating a stocking density of six horses for four hours per day. The manure was obtained daily from the Flyinge Depot, following the procedure described by von Wachenfelt [15]. The manure was manually distributed over the test area just before the start of the experiment and then removed manually (manure removal), while in the second experiment the manure (approximately 75 $\mathrm{kg}$ ) was allowed to accumulate on the test area surface during five days (manure accumulation).

The manure and fluid samples were analysed for total nitrogen (TN), total ammoniacal nitrogen (TAN), total phosphorus (TP), chemical oxygen demand (COD) and total solids (TS) according to ISS [17]. The manure characteristic values (Table 1), without bedding material, complied with those reported by Kemira [18] and Caselles [7]. 
Horse manure differs from cattle manure by its higher TS (135\%) and TP (400\%) concentrations and its lower concentrations of TN (50\%) and TAN (14\%) compared with cattle manure. Moreover, the COD level in horse manure is 46 -fold higher than in cattle manure, according to Singh [16].

\subsection{Test Area Construction}

The excavated test areas, measuring $2 \mathrm{~m}$ by $6 \mathrm{~m}$ each, had a uniform 3\% slope along the major axis and were cross-levelled along the minor axis. The test areas followed the design described in Ref. [15], except for finer gravel use and a different runoff collection system (Fig. 1).

The gravel fractions used in this study were $16 \mathrm{~mm}$ coarse $(150 \mathrm{~mm})$ with $5 \mathrm{~mm}$ fine gravel $(50 \mathrm{~mm})$ on top, compared with 16-32 mm coarse gravel (150 mm) and a layer of 8-16 $\mathrm{mm}$ gravel $(50 \mathrm{~mm})$ on top in the study [15]. The last $1 \mathrm{~m}$ of the test area surface formed the basis for runoff collection. A membrane was placed $10 \mathrm{~cm}$ under the gravel surface to divert the runoff to a $50 \mathrm{~mm}$ subsurface drain pipe. Runoff, drainage effluent and leachate flow were sampled as they exited the respective pipes in a measuring station, one for each paddock.

\subsection{Sampling of Runoff, Drainage Effluent and Leachate}

The fluid sampling and experimental set-up were kept the same throughout the experiments. During the winter seasons, the naturally occurring precipitation on the paddock test areas and manure deposition by horses using the paddocks were utilised. The paddock size differed, with one occupying $150 \mathrm{~m}^{2}$ and the other $900 \mathrm{~m}^{2}$, but the treatment areas were located in the vicinity of the main entrance in both paddocks. The horse density was one horse in the smaller paddock and two horses in the larger paddock. Every other week, the manure was either removed daily or accumulated for a week. The local weather conditions were based on weather data obtained during sampling (Fig. 2). Unfortunately the first year of winter sampling was characterised by a long dry period, leaving only one season of measurements. The ambient temperature was $17 \pm 4{ }^{\circ} \mathrm{C}$ and the humidity $52 \% \pm 18 \%$ during the SR experimental period.

Pipes from each paddock entered a measuring station, where a tipping bucket together with a logger

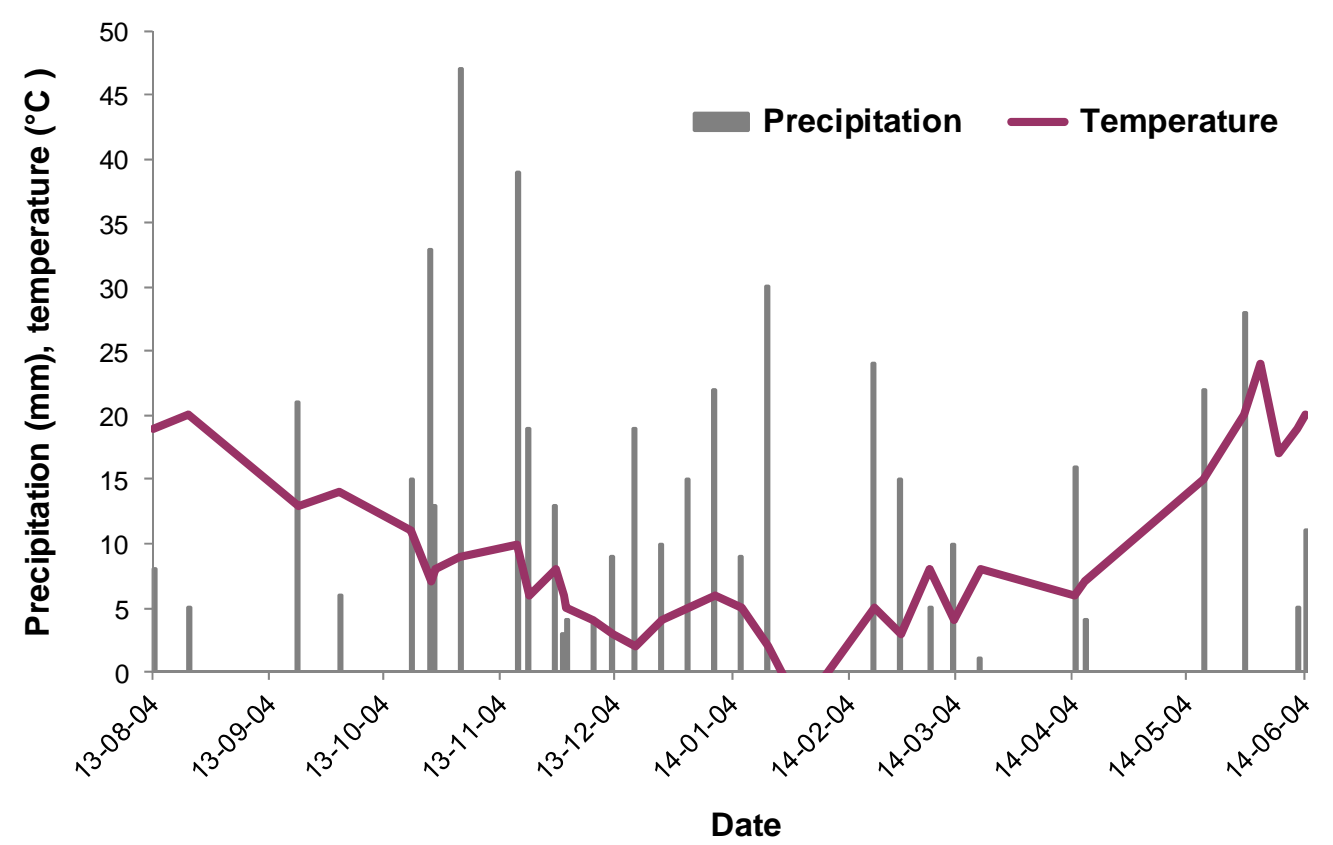

Fig. 2 Measured precipitation (grey bars) and air temperature (red line) at 09: 00 during the experimental period. 
recorded the flow of each fluid (runoff, drainage effluent and leachate). The loggers (Tinytag count input data logger, Gemini Data Loggers, Chichester, UK) had a sampling frequency set for once per minute and each bucket was calibrated at different flow rates. The fluid flow calculation was based on total flow time, total number of recordings and the calibrated flow rates. The average total time for the drains to flow was approximately $2.6 \mathrm{~h}$. With intermittent sampling from the tipping buckets, a flow-weighted composite sample was obtained. Total fluid volume of runoff, drainage effluent and leachate was then calculated. Mass values for fluid constituents were obtained by multiplying the fluid concentrations of each constituent by the respective fluid volume. All samples were frozen directly after sampling.

To simulate an outdoor area with horse manure during a rainstorm event, a rainfall simulator capable of applying $50 \mathrm{~mm}$ for 30 minutes per treatment was used to generate runoff and drainage effluent from the test area (Fig. 3), as described by von Wachenfelt [15].

\subsection{Statistical Analysis}

The experiment had a split-plot design without blocks, with manure removal or accumulation as main plot factor and treatments 1-3 as split-plot factor. Analysis of variance using PROC MIXED in SAS Institute Inc. [19] was performed, following the procedure described by von Wachenfelt [15], to determine the effect of manure removal or accumulation and treatment combinations on the content of TS, COD and nutrients in sample fluids and in fluid flows. The following statistical model was used:

$$
Y_{i j k l}=\mu+\alpha_{i}+\beta_{j}+(\alpha \beta)_{i j}+\gamma_{k(i)}+e_{i j k l}
$$

where, $\mu=$ treatment mean, $\alpha_{i}=$ manure removal or accumulation, $\beta_{j}=$ geotextile test area treatment, $\gamma_{k(i j)}=$ random effect of replication, $e_{i j k}=$ error term, $i$ $=$ manure level $(1,2), j=$ geotextile test area treatment level (1, 2, 3), $k=$ number of main plots $(1,2,3,4,5)$ and $l=$ number of replicates in each main plot $(1,2)$.

\section{Results}

\subsection{Measurement Results from All Seasons}

The second winter season, from October 2013 to March 2014, was rainy except for a frosty period at the end of January (Fig. 2). All winter measurements

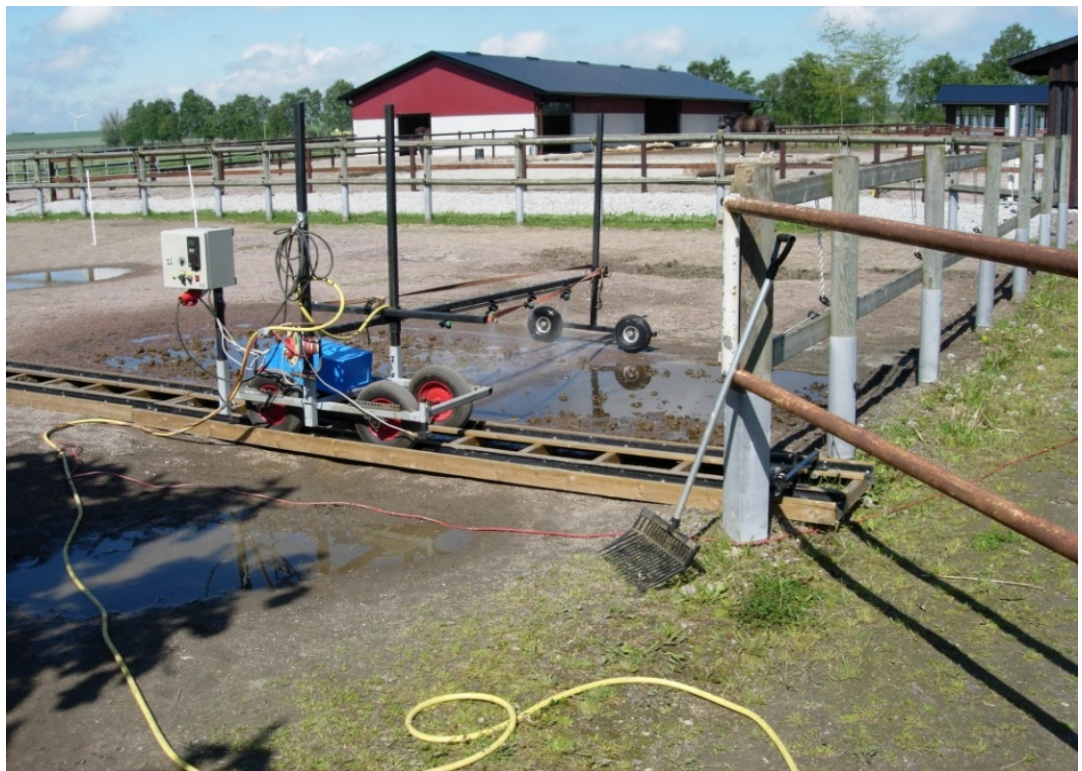

Fig. 3 Rainfall simulator at work. The boundaries of the test area are determined by the simulator rail and the spray boom. Run-off drain was placed $0.25 \mathrm{~m}$ inside and along the fence to which the slope direction was. 
for each paddock are presented as mean values (Table 2), as neither experimental nor treatment differences had a significant effect on TS, COD and nutrient concentrations in sample fluids.

The runoff rate was low, or completely absent in the case of the Single geotextile treatment, probably because of poor function of the runoff collection system. However, for drainage effluent and leachate the number of samples ranged from 9 to 14. As expected, the concentrations of pollutants were lower in fluids from paddock 1 than from paddock 2, because of the lower horse density.

In general, the fluid concentrations were low. The one exception was $\mathrm{TP}, \mathrm{NO}_{3}-\mathrm{N}$ and TS in the Single geotextile treatment, but this was due to a 6-minute summer rainstorm of $24 \mathrm{~mm}$ after the first winter season without precipitation. During the winter months of the second season there was a general increase in fluid concentrations of pollutants, for example for TN in the Gravel treatment, but especially for TP runoff in both the Combined and Gravel treatments (1.23 $\mathrm{mgL}^{-1}$ and $2.30 \mathrm{mgL}^{-1}$, respectively).

\subsection{Fluid Flow Rate}

In the following, the results from the simulated rainfall study are presented. The study was performed at the end of the two-year period. The fluid flows through the geotextile gravel test areas are shown in Table 3 for each experimental set-up. The function of the runoff collection system varied between replicates. Although it maintained the same average rate in both experiments, it continued to be very uneven between replicates, which resulted in high SD values for most fluid flows. A typical example was the Gravel pad runoff flow in both experiments. In the Single treatment, the runoff was lower and the drain flow significantly lower than from the other test areas and continued to be so in the manure removal experiment. The mean drainage effluent flow rate ranged between $2.4 \mathrm{~L} \mathrm{~m}^{-2} \mathrm{~h}^{-1}$ and $4.6 \mathrm{~L} \mathrm{~m}^{-2} \mathrm{~h}^{-1}$ and the mean leachate flow rate between $0.7 \mathrm{~L} \mathrm{~m}^{-2} \mathrm{~h}^{-1}$ and $3.6 \mathrm{~L} \mathrm{~m}^{-2} \mathrm{~h}^{-1}$ in the manure removal experiment, while the corresponding

Table 2 Empirical results for different seasons of the year, 2013-2014, from the geotextile-gravel beds. Comparison between different geotextile-gravel bed treatments (number of samples (n), mean and standard deviation (SD)).

\begin{tabular}{|c|c|c|c|c|c|c|c|c|c|c|c|c|}
\hline \multirow{3}{*}{\multicolumn{2}{|c|}{ Parameter }} & \multicolumn{11}{|c|}{ Treatment } \\
\hline & & \multicolumn{5}{|c|}{ Combined geotextile } & \multicolumn{3}{|c|}{ Single geotextile $^{\mathrm{a}}$} & \multicolumn{3}{|c|}{ Gravel } \\
\hline & & \multicolumn{2}{|l|}{ Runoff } & \multirow{2}{*}{$\begin{array}{l}\text { Drain } \\
\text { Mean (SD) }\end{array}$} & \multirow{2}{*}{$\begin{array}{l}\text { Leachate } \\
\text { Mean (SD) }\end{array}$} & \multirow[b]{2}{*}{$\mathrm{n}$} & \multirow{2}{*}{$\begin{array}{l}\text { Drain } \\
\text { Mean (SD) } \\
\end{array}$} & \multirow{2}{*}{$\begin{array}{l}\text { Leachate } \\
\text { Mean (SD) } \\
\end{array}$} & \multirow[b]{2}{*}{$\mathrm{n}$} & \multirow{2}{*}{$\begin{array}{l}\text { Runoff } \\
\text { Mean (SD) }\end{array}$} & \multirow{2}{*}{\multicolumn{2}{|c|}{$\begin{array}{ll} & \text { Drain } \\
\mathrm{n} & \text { Mean (SD) }\end{array}$}} \\
\hline & $\mathrm{n}$ & Mean (SD) & $\mathrm{n}$ & & & & & & & & & \\
\hline \multicolumn{13}{|c|}{ Paddock 1, summer-autumn-winter-spring measurements } \\
\hline $\mathrm{TN}\left(\mathrm{mg} \mathrm{L}^{-1}\right)$ & & 0 & 14 & $2.0(0.3)$ & $2.4(1.3)$ & 9 & $2.4(0.7)$ & $2.2(0.8)$ & 1 & 1.9 & 14 & $1.9(0.0)$ \\
\hline TAN (mg L $\left.{ }^{-1}\right)$ & & 0 & 14 & $0.1(0.3)$ & $0.7(1.4)$ & 9 & $0.2(0.4)$ & $0.3(0.6)$ & 1 & 0.06 & 14 & $0.1(0.2)$ \\
\hline $\mathrm{NO}_{3}-\mathrm{N}\left(\mathrm{mg} \mathrm{L}^{-1}\right)$ & & 0 & 14 & $6.0(5.5)$ & $8.6(10.6)$ & 9 & 7.5 (5.7) & $10.4(9.8)$ & 1 & 12.0 & 14 & 9.0 (7.7) \\
\hline $\mathrm{NO}_{2}-\mathrm{N}\left(\mathrm{mg} \mathrm{L}^{-1}\right)$ & & 0 & 14 & $0.06(0.16)$ & $0.11(0.22)$ & 9 & $0.03(0.04)$ & $0.08(0.19)$ & 1 & 0.93 & 14 & $0.06(0.10)$ \\
\hline $\mathrm{TP}\left(\mathrm{mg} \mathrm{L}^{-1}\right)$ & & 0 & 14 & $0.07(0.04)$ & $0.05(0.02)$ & 9 & $0.18(0.21)$ & $0.06(0.05)$ & 1 & 0.05 & 14 & $0.16(0.08)$ \\
\hline $\operatorname{COD}\left(\mathrm{mg} \mathrm{L}^{-1}\right)$ & & 0 & 14 & $35(10)$ & $34(12)$ & 9 & $48(29)$ & $36(17)$ & 1 & 52 & 14 & $32(5)$ \\
\hline $\mathrm{TS}\left(\mathrm{mg} \mathrm{L}^{-1}\right)$ & & 0 & 14 & $286(128)$ & $312(164)$ & 9 & 355 (175) & $318(110)$ & 1 & 190 & 14 & $314(110)$ \\
\hline \multicolumn{13}{|c|}{ Paddock 2, summer-autumn-winter-spring measurements } \\
\hline $\mathrm{TN}\left(\mathrm{mg} \mathrm{L}^{-1}\right)$ & 3 & $5.3(3.2)$ & 14 & $3.1(3.7)$ & $2.8(1.7)$ & 14 & $2.4(1.3)$ & $3.8(3.7)$ & 3 & $7.2(5.9)^{\mathbf{d}}$ & 14 & $3.3(2.3)$ \\
\hline TAN (mg L $\left.{ }^{-1}\right)$ & 3 & $0.4(1.0)$ & 14 & $0.4(1.0)$ & $0.4(0.3)$ & 14 & $0.3(0.5)$ & $1.1(2.1)$ & 3 & $0.3(0.1)$ & 14 & $1.1(1.3)$ \\
\hline $\mathrm{NO}_{3}-\mathrm{N}\left(\mathrm{mg} \mathrm{L}^{-1}\right)$ & 3 & $1.4(1.2)$ & 14 & $10.9(9.3)$ & $13.9(11.3)^{\mathbf{b}}$ & 14 & $24.6(51.9)^{\mathbf{b}}$ & $43.5(76.3)^{\mathbf{b}}$ & 3 & $2.0(1.5)$ & 14 & $11.3(16.2)$ \\
\hline $\mathrm{NO}_{2}-\mathrm{N}\left(\mathrm{mg} \mathrm{L}^{-1}\right)$ & 3 & $0.03(0.04)$ & 14 & $0.27(0.45)$ & 1.19 (3.30) & 14 & $0.08(0.17)$ & $0.60(1.30)$ & 3 & $0.03(0.03)$ & 14 & $0.15(0.30)$ \\
\hline $\mathrm{TP}\left(\mathrm{mg} \mathrm{L}^{-1}\right)$ & 3 & $1.23(0.87)$ & 14 & $0.27(0.41)$ & $0.19(0.33)$ & 14 & $0.08(0.06)$ & $0.05(0.05)$ & 3 & $2.30(0.57)^{\mathbf{c}}$ & 14 & $0.14(0.14)^{\mathrm{c}}$ \\
\hline $\operatorname{COD}\left(\mathrm{mg} \mathrm{L}^{-1}\right)$ & 3 & $86(56)$ & 14 & $40(14)$ & $38(14)$ & 14 & $42(16)$ & $56(31)$ & 3 & $162(102)^{c}$ & 14 & $41(17)$ \\
\hline $\mathrm{TS}\left(\mathrm{mg} \mathrm{L}^{-1}\right)$ & 3 & 270 (89) & 14 & $516(281)$ & 591 (293) & 14 & $589(504)$ & $906(672)^{b}$ & 3 & 403 (214) & 14 & $468(201)$ \\
\hline
\end{tabular}

a-Runoff not measured in the Single geotextile treatment; b-Peak values from measurements during summer time; c-Peak values from measurement during winter time; $\mathrm{d}$-Peak values from measurements at winter-spring flood. 
Table 3 Fluid flow $\left(\mathrm{L} \mathrm{m}^{-2} \mathrm{~h}^{-1}\right)$ in the geotextile-gravel test areas. Comparison between different geotextile material combinations and between manure accumulation and removal (number of samples (n), least square means and standard deviation (SD)).

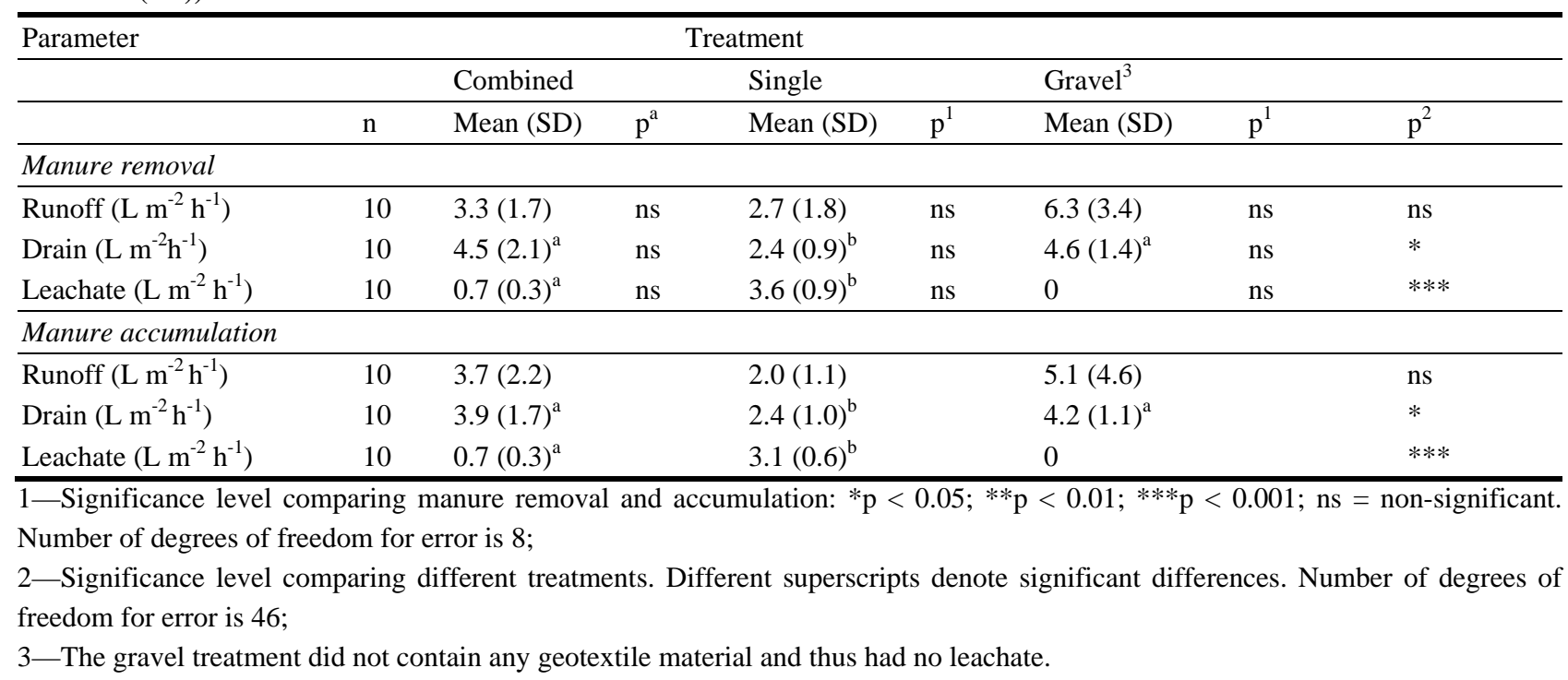

Table 4 Pollutant concentrations $\left(\mathrm{mg} \mathrm{L}^{-1}\right)$ in runoff from the geotextile-gravel beds. Comparison between different geotextile material combinations (treatments) and between manure accumulation and removal (number of samples (n), least square means and standard deviation (SD)).

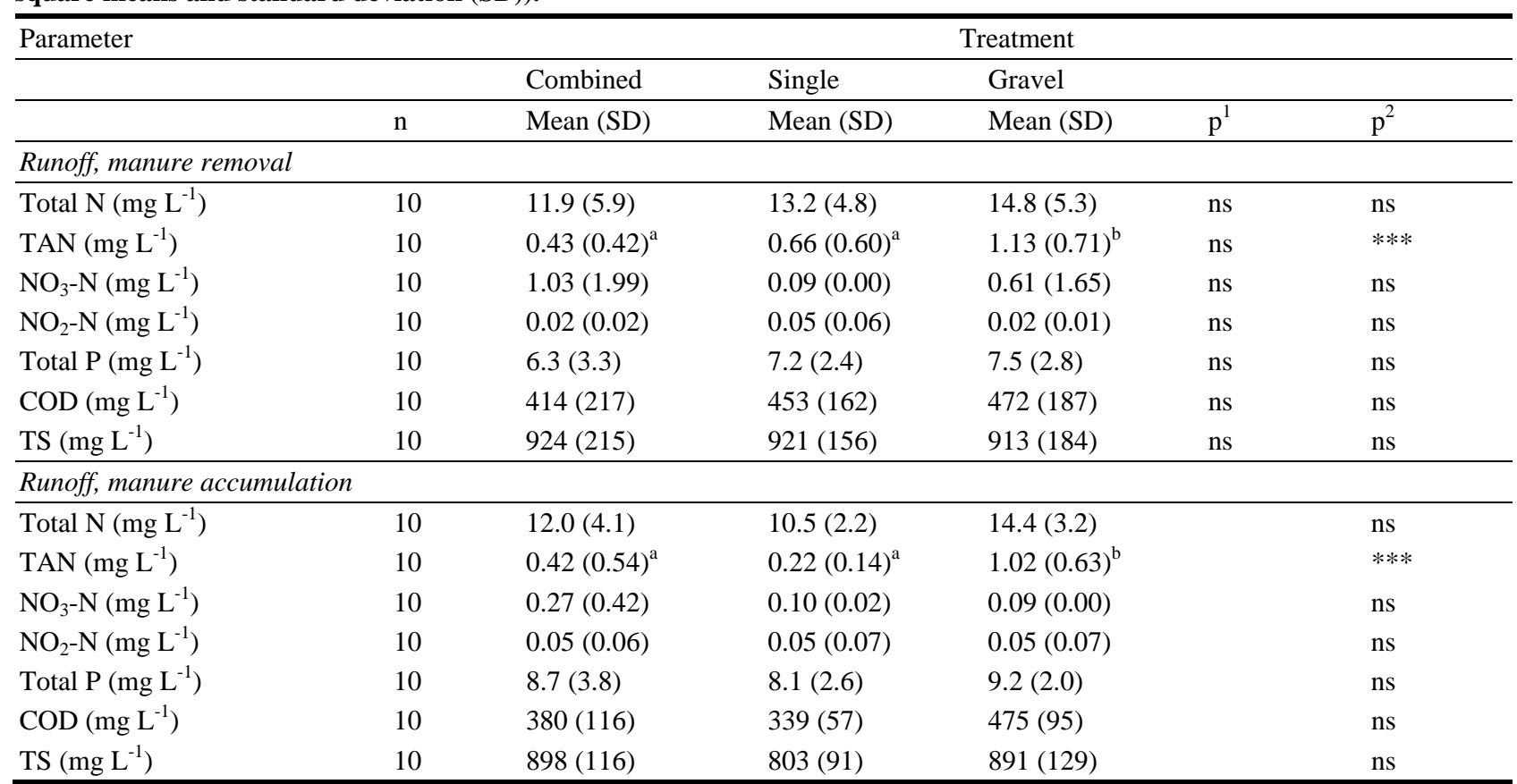

1-Significance level comparing manure removal and accumulation: ${ }^{*} \mathrm{p}<0.05$; ${ }^{* *} \mathrm{p}<0.01 ;{ }^{* * *} \mathrm{p}<0.001$; ns $=$ non-significant. Number of degrees of freedom for error is 8 ;

2-Significance level comparing different treatments. Different superscripts denote significant differences. Number of degrees of freedom for error is 46 .

flow rates were 2.4-4.2 and 0.7-3.1 $\mathrm{L} \mathrm{m}^{-2} \mathrm{~h}^{-1}$, respectively, in the manure accumulation experiment. The drain flow rate was uneven between replicates in both experiments, which resulted in SD values of the same range and order, with the exception of the Gravel treatment. 
For the Combined treatment, the leachate flow was significantly lower (79\%) than in the Single treatment in both experiments, with small variability between replicates.

\subsection{Runoff}

The treatment effects on runoff with manure removal and manure accumulation are shown in Tables 4 and 5. For TAN there was a treatment effect, with a lower TAN value for the Combined and Single treatments of $0.43 \mathrm{mg} \mathrm{L}^{-1}$ and $0.42 \mathrm{mg} \mathrm{L}^{-1}\left(2.0 \mathrm{mg} \mathrm{m}^{-2}\right.$ and $2.2 \mathrm{mg} \mathrm{m}^{-2}$ ) and $0.66 \mathrm{mg} \mathrm{L}^{-1}$ and $0.22 \mathrm{mg} \mathrm{L}^{-1}(1.2$ $\mathrm{mg} \mathrm{m}^{-2}$ and $0.4 \mathrm{mg} \mathrm{m}^{-2}$ ), respectively, compared with Gravel (1.13 $\mathrm{mg} \mathrm{L}^{-1}$ and $1.02 \mathrm{mg} \mathrm{L}^{-1} ; 6.8 \mathrm{mg} \mathrm{m}^{-2}$ and $3.2 \mathrm{mg} \mathrm{m}^{-2}$ ) in the experiments with and without manure removal. Nitrate and nitrite levels showed no significant experimental or treatment differences, but nitrate levels were higher for both the Combined and Gravel treatments with manure removal and the Combined treatment in both experiments, compared with the Single treatment. The range of nitrite was almost the same in both experiments and in all treatments. The average concentration of nitrate in runoff was $0.37 \mathrm{mg} \mathrm{L}^{-1}$ and that of nitrite was $0.04 \mathrm{mg} \mathrm{L}^{-1}$.

\subsection{Drainage Effluent}

An experimental effect was found for TP, COD and TS in drainage effluent, with a mean reduction in concentration of 51\%, 26\% and 15\%, respectively, due to manure removal (Table 6). The mean COD reduction

Table 5 Comparison of nutrient content $\left(\mathrm{mg} \mathrm{m}^{-2}\right.$ test area) in runoff, drain and leachate as an effect of manure removal and accumulation and different geotextile-gravel bed treatments (number of samples (n), mean and standard deviation (SD)) during simulated rainfall test.

\begin{tabular}{|c|c|c|c|c|}
\hline \multirow[t]{2}{*}{ Parameter } & & \multicolumn{3}{|c|}{ Treatment } \\
\hline & & Combined & Single & Gravel \\
\hline & $\mathrm{n}$ & Mean (SD) & Mean (SD) & Mean (SD) \\
\hline \multicolumn{5}{|l|}{ Manure removal } \\
\hline Runoff TAN (mg m²) & 10 & $2.0(2.5)$ & $1.2(1.1)$ & $6.8(6.1)$ \\
\hline Drain total $\mathrm{N}\left(\mathrm{mg} \mathrm{m}^{-2}\right)$ & 10 & $34(36)$ & $13(8)$ & $44(11)$ \\
\hline Drain total P (mg m $\left.{ }^{-2}\right)$ & 10 & $16.6(20.4)$ & $4.8(4.1)$ & $21.5(5.3)$ \\
\hline Drain COD $\left(\mathrm{mg} \mathrm{m}^{-2}\right)$ & 10 & $1,010(1,114)$ & $390(267)$ & $1,380(367)$ \\
\hline Drain TS (mg m $\left.{ }^{-2}\right)$ & 10 & $3,093(2,082)$ & $1,626(676)$ & $3,640(1,045)$ \\
\hline Leachate total $\mathrm{N}\left(\mathrm{mg} \mathrm{m}^{-2}\right)$ & 10 & $3(4)$ & $16(7)$ & \\
\hline Leachate TAN (mg m $\left.{ }^{-2}\right)$ & 10 & $0.1(0.3)$ & $0.3(0.3)$ & \\
\hline Leachate $\mathrm{NO}_{3}-\mathrm{N}\left(\mathrm{mg} \mathrm{m}^{-2}\right)$ & 10 & $3.5(2.9)$ & $28.7(10.6)$ & \\
\hline Leachate $\mathrm{NO}_{2}-\mathrm{N}\left(\mathrm{mg} \mathrm{m}^{-2}\right)$ & 10 & $0.04(0.04)$ & $0.49(1.25)$ & \\
\hline Leachate total P ( $\left.\mathrm{mg} \mathrm{m}^{-2}\right)$ & 10 & $0.1(0.1)$ & $4.3(2.9)$ & \\
\hline Leachate COD ( $\left.\mathrm{mg} \mathrm{m}^{-2}\right)$ & 10 & $92(114)$ & $440(235)$ & \\
\hline Leachate TS $\left(\mathrm{mg} \mathrm{m}^{-2}\right)$ & 10 & $454(198)$ & $2,443(790)$ & \\
\hline \multicolumn{5}{|l|}{ Manure accumulation } \\
\hline Runoff TAN (mg m ${ }^{-2}$ ) & 10 & $2.2(3.1)$ & $0.4(0.3)$ & $3.2(4.1)$ \\
\hline Drain total $\mathrm{N}\left(\mathrm{mg} \mathrm{m}^{-2}\right)$ & 10 & $40(28)$ & $16(8)$ & $49(14)$ \\
\hline Drain total P $\left(\mathrm{mg} \mathrm{m}^{-2}\right)$ & 10 & $25.6(20.6)$ & $10.9(5.9)$ & $34.7(15.2)$ \\
\hline Drain COD $\left(\mathrm{mg} \mathrm{m}^{-2}\right)$ & 10 & $1,253(973)$ & 539 (263) & $1,555(471)$ \\
\hline Drain TS $\left(\mathrm{mg} \mathrm{m}^{-2}\right)$ & 10 & $3,488(1,797)$ & $1,831(813)$ & $3,657(1,064)$ \\
\hline Leachate total $\mathrm{N}\left(\mathrm{mg} \mathrm{m}^{-2}\right)$ & 10 & $5(4)$ & $20(11)$ & \\
\hline Leachate TAN (mg m $\left.{ }^{-2}\right)$ & 10 & $0.1(0.1)$ & $0.4(0.5)$ & \\
\hline Leachate $\mathrm{NO}_{3}-\mathrm{N}\left(\mathrm{mg} \mathrm{m}^{-2}\right)$ & 10 & $5.1(2.2)$ & $17.3(7.1)$ & \\
\hline Leachate $\mathrm{NO}_{2}-\mathrm{N}\left(\mathrm{mg} \mathrm{m}^{-2}\right)$ & 10 & $0.03(0.02)$ & $0.13(0.25)$ & \\
\hline Leachate total P (mg m $\left.{ }^{-2}\right)$ & 10 & $2.7(2.4)$ & $8.2(5.9)$ & \\
\hline Leachate COD (mg m $\left.{ }^{-2}\right)$ & 10 & $148(120)$ & $560(301)$ & \\
\hline Leachate TS (mg m $\left.{ }^{-2}\right)$ & 10 & $538(230)$ & $2,416(732)$ & \\
\hline
\end{tabular}


Table 6 Drain fluid concentration $\left(\mathrm{mg} \mathrm{L}^{-1}\right)$ in the geotextile-gravel beds. Comparison between different geotextile material combinations (treatments) and between manure accumulation and removal (number of samples (n), least square means and standard deviation (SD)).

\begin{tabular}{|c|c|c|c|c|c|c|}
\hline \multirow[t]{3}{*}{ Parameter } & & \multicolumn{5}{|c|}{ Treatment } \\
\hline & \multirow[b]{2}{*}{$\mathrm{n}$} & \multirow{2}{*}{$\begin{array}{l}\text { Combined } \\
\text { Mean (SD) }\end{array}$} & \multirow{2}{*}{$\begin{array}{l}\text { Single } \\
\text { Mean (SD) }\end{array}$} & \multicolumn{3}{|l|}{ Gravel } \\
\hline & & & & Mean (SD) & $\mathrm{p}^{1}$ & $\mathrm{p}^{2}$ \\
\hline \multicolumn{7}{|c|}{ Drain, manure removal } \\
\hline Total N (mg L $\left.{ }^{-1}\right)$ & 10 & $7.5(5.3)^{\mathrm{a}}$ & $5.2(2.6)^{b}$ & $10.0(2.1)^{\mathrm{a}}$ & ns & $* * *$ \\
\hline TAN $\left(\mathrm{mg} \mathrm{L}^{-1}\right)$ & 10 & $0.24(0.22)$ & $0.07(0.04)$ & $0.28(0.23)$ & ns & ns \\
\hline $\mathrm{NO}_{3}-\mathrm{N}\left(\mathrm{mg} \mathrm{L}^{-1}\right)$ & 10 & $2.49(2.77)$ & $3.29(4.14)$ & $0.81(2.00)$ & ns & ns \\
\hline $\mathrm{NO}_{2}-\mathrm{N}\left(\mathrm{mg} \mathrm{L}^{-1}\right)$ & 10 & $0.02(0.02)$ & $0.11(0.25)$ & $0.02(0.03)$ & ns & ns \\
\hline Total P $\left(\mathrm{mg} \mathrm{L}^{-1}\right)$ & 10 & $3.4(3.3)^{\mathrm{a}}$ & $1.9(1.4)^{\mathrm{a}}$ & $5.0(1.4)^{\mathrm{b}}$ & $*$ & $* * *$ \\
\hline COD $\left(\mathrm{mg} \mathrm{L}^{-1}\right)$ & 10 & $220(176)^{\mathrm{a}}$ & $156(92)^{\mathrm{a}}$ & $316(71)^{b}$ & $*$ & $* * *$ \\
\hline $\mathrm{TS}\left(\mathrm{mg} \mathrm{L}^{-1}\right)$ & 10 & $748(160)^{\mathrm{a}}$ & $654(155)^{\mathrm{b}}$ & $814(116)^{\mathrm{a}}$ & * & $* * *$ \\
\hline \multicolumn{7}{|c|}{ Drain, manure accumulation } \\
\hline Total N $\left(\mathrm{mg} \mathrm{L}^{-1}\right)$ & 10 & $9.6(4.2)^{\mathrm{a}}$ & $6.9(1.7)^{\mathrm{b}}$ & $11.9(2.0)^{\mathrm{a}}$ & & $* * *$ \\
\hline TAN $\left(\mathrm{mg} \mathrm{L}^{-1}\right)$ & 10 & $0.28(0.39)$ & $0.23(0.38)$ & $0.26(0.27)$ & & ns \\
\hline $\mathrm{NO}_{3}-\mathrm{N}\left(\mathrm{mg} \mathrm{L}^{-1}\right)$ & 10 & $0.71(1.20)$ & $0.81(0.82)$ & $0.11(0.02)$ & & ns \\
\hline $\mathrm{NO}_{2}-\mathrm{N}\left(\mathrm{mg} \mathrm{L}^{-1}\right)$ & 10 & $0.04(0.05)$ & $0.03(0.03)$ & $0.04(0.07)$ & & ns \\
\hline Total P $\left(\mathrm{mg} \mathrm{L}^{-1}\right)$ & 10 & $6.2(4.1)^{\mathrm{a}}$ & $4.6(1.5)^{\mathrm{a}}$ & $8.3(2.6)^{\mathrm{b}}$ & & $* * *$ \\
\hline $\mathrm{COD}\left(\mathrm{mg} \mathrm{L}^{-1}\right)$ & 10 & $290(123)^{\mathrm{a}}$ & $221(53)^{\mathrm{a}}$ & $379(77)^{\mathrm{b}}$ & & $* * *$ \\
\hline $\mathrm{TS}\left(\mathrm{mg} \mathrm{L}^{-1}\right)$ & 10 & $886(106)^{\mathrm{a}}$ & $764(51)^{\mathrm{b}}$ & $886(95)^{\mathrm{a}}$ & & $* * *$ \\
\hline
\end{tabular}

1-Significance level comparing manure removal and accumulation: ${ }^{*} \mathrm{p}<0.05$; ${ }^{* *} \mathrm{p}<0.01$; ${ }^{* * *} \mathrm{p}<0.001$; ns $=$ non-significant. Number of degrees of freedom for error is 8;

2-Significance level comparing different treatments. Different superscripts denote significant differences. Number of degrees of freedom for error is 46 .

ranged from $188 \mathrm{mg} \mathrm{L}^{-1}\left(700 \mathrm{mg} \mathrm{m}^{-2}\right)$ with manure removal to $255 \mathrm{mg} \mathrm{L}^{-1}$ (896 $\mathrm{mg} \mathrm{m}^{-2}$ ) with manure accumulation. Nitrate and nitrite levels showed no significant experimental or treatment differences, but for nitrate levels there was an effect in the experiment with manure removal. Nitrate levels were kept in the same range in both experiments and for all treatments, except for a higher value in the Single treatment in the manure removal experiment. The mean concentration of nitrate in the geotextile treatments in both experiments was $1.83 \mathrm{mg} \mathrm{L}^{-1}$ and that of nitrite 0.05 $\mathrm{mg} \mathrm{L}^{-1}$.

For the Single treatment, a treatment effect was found for TN in drainage effluent, with a TN value of $5.2 \mathrm{mg} \mathrm{L}^{-1}$ for manure removal and $6.9 \mathrm{mg} \mathrm{L}^{-1}$ for manure accumulation, which could be compared to an all treatment mean TN value of $7.6 \mathrm{mg} \mathrm{L}^{-1}$ for manure removal and $9.5 \mathrm{mg} \mathrm{L}^{-1}$ for manure accumulation. The all treatment mean nutrient content per unit area for manure removal (30 $\mathrm{mg} \mathrm{m}^{-2}$ ) was $13 \%$ lower than for manure accumulation.

The treatment effect on TP, COD and TS resulted in significantly lower concentrations for the Single geotextile treatment with manure removal $(1.9,156$, $654 \mathrm{mg} \mathrm{L}^{-1}$ and 4.8, 390, 1,626 $\mathrm{mg} \mathrm{m}^{-2}$ ) and manure accumulation (4.6, 221, $764 \mathrm{mg} \mathrm{L}^{-1}$ and 10.9, 539, $1,831 \mathrm{mg} \mathrm{m}^{-2}$ ) compared with the other treatments.

\subsection{Leachate}

Comparing drainage effluent and leachate (Table 7), all concentrations were lower in leachate except for $\mathrm{NO}_{3}-\mathrm{N}$ and $\mathrm{NO}_{2}-\mathrm{N}$. With manure removal, the concentrations in leachate showed a decreasing tendency for almost all parameters in the Single treatment except for $\mathrm{NO}_{3}-\mathrm{N}$ and $\mathrm{NO}_{2}-\mathrm{N}$. There was an experiment $\mathrm{x}$ treatment effect for $\mathrm{NO}_{3}-\mathrm{N}$, with higher nitrate values for the Single compared with the Combined treatment in the manure removal experiment. 
Table 7 Leachate fluid concentration $\left(\mathrm{mg} \mathrm{L}^{-1}\right)$ in the geotextile-gravel beds. Comparison between different geotextile material combinations (treatments) and between manure accumulation and removal (number of samples (n), least square means and standard deviation (SD)).

\begin{tabular}{|c|c|c|c|c|c|c|}
\hline \multirow[t]{3}{*}{ Parameter } & & \multicolumn{5}{|c|}{ Treatment } \\
\hline & & \multirow{2}{*}{$\begin{array}{l}\text { Combined } \\
\text { Mean (SD) } \\
\end{array}$} & \multirow{2}{*}{$\begin{array}{l}\text { Single } \\
\text { Mean (SD) }\end{array}$} & \multicolumn{3}{|l|}{ Gravel $^{3}$} \\
\hline & $\mathrm{n}$ & & & Mean (SD) & $\mathrm{p}^{1}$ & $\mathrm{p}^{2}$ \\
\hline \multicolumn{7}{|c|}{ Leachate, manure removal } \\
\hline Total N (mg L $\left.{ }^{-1}\right)$ & 10 & $4.3(4.0)$ & $4.5(1.8)$ & 0 & ns & ns \\
\hline TAN $\left(\mathrm{mg} \mathrm{L}^{-1}\right)$ & 10 & $0.16(0.28)$ & $0.07(0.06)$ & 0 & ns & ns \\
\hline $\mathrm{NO}_{3}-\mathrm{N}\left(\mathrm{mg} \mathrm{L}^{-1}\right)$ & 10 & $5.82(3.93)$ & $8.23(3.15)$ & 0 & ns & ns \\
\hline $\mathrm{NO}_{2}-\mathrm{N}\left(\mathrm{mg} \mathrm{L}^{-1}\right)$ & 10 & $0.05(0.04)$ & $0.10(0.24)$ & 0 & ns & ns \\
\hline Total P (mg L $\left.{ }^{-1}\right)$ & 10 & $1.6(2.4)$ & $1.2(0.7)$ & 0 & $*$ & ns \\
\hline $\mathrm{COD}\left(\mathrm{mg} \mathrm{L}^{-1}\right)$ & 10 & $123(132)$ & $122(54)$ & 0 & ns & ns \\
\hline $\mathrm{TS}\left(\mathrm{mg} \mathrm{L}^{-1}\right)$ & 10 & $698(147)$ & $673(125)$ & 0 & ns & ns \\
\hline \multicolumn{7}{|c|}{ Leachate, manure accumulation } \\
\hline Total N (mg L $\left.{ }^{-1}\right)$ & 10 & $6.6(3.5)$ & $6.2(2.2)$ & 0 & & ns \\
\hline TAN $\left(\mathrm{mg} \mathrm{L}^{-1}\right)$ & 10 & $0.08(0.05)$ & $0.12(0.14)$ & 0 & & ns \\
\hline $\mathrm{NO}_{3}-\mathrm{N}\left(\mathrm{mg} \mathrm{L}^{-1}\right)$ & 10 & $7.56(1.60)$ & $5.54(2.02)$ & 0 & & ns \\
\hline $\mathrm{NO}_{2}-\mathrm{N}\left(\mathrm{mg} \mathrm{L}^{-1}\right)$ & 10 & $0.05(0.03)$ & $0.04(0.07)$ & 0 & & ns \\
\hline Total P $\left(\mathrm{mg} \mathrm{L}^{-1}\right)$ & 10 & $3.3(2.4)$ & $2.5(1.3)$ & 0 & & ns \\
\hline Total COD $\left(\mathrm{mg} \mathrm{L}^{-1}\right)$ & 10 & $187(105)$ & 172 (59) & 0 & & ns \\
\hline Total TS (mg L $\left.{ }^{-1}\right)$ & 10 & $797(84)$ & $767(84)$ & 0 & & ns \\
\hline
\end{tabular}

1-Significance level comparing manure removal and accumulation: ${ }^{*} \mathrm{p}<0.05$; ${ }^{* *} \mathrm{p}<0.01$; ${ }^{* * *} \mathrm{p}<0.001$; ns $=$ non-significant. Number of degrees of freedom for error is 8;

2-Significance level comparing different treatments. Different superscripts denote significant differences. Number of degrees of freedom for error is 46 ;

3-The gravel treatment did not contain any geotextile material and thus had no leachate.

The average $\mathrm{NO}_{3}-\mathrm{N}$ and $\mathrm{NO}_{2}-\mathrm{N}$ concentrations in leachate were $7.0 \mathrm{mg} \mathrm{L}^{-1}, 0.08 \mathrm{mg} \mathrm{L}^{-1}$ and $16 \mathrm{mg} \mathrm{m}^{-2}$, $11.2 \mathrm{mg} \mathrm{m}^{-2}$, respectively, for manure removal were $6.6 \mathrm{mg} \mathrm{L}^{-1}, 0.05 \mathrm{mg} \mathrm{L}^{-1}$ and $0.27 \mathrm{mg} \mathrm{m}^{-2}, 0.08 \mathrm{mg} \mathrm{m}^{-2}$ test area, respectively, for manure accumulation.

A mean experimental effect, i.e. the mean value of both treatments, was found on leachate concentration for TP, decreasing by $48 \%$ with a corresponding decrease in nutrient content per $\mathrm{m}^{2}$ by approx. $40 \%$ for manure removal compared with manure accumulation. The mean TP reduction ranged from $1.4 \mathrm{mg} \mathrm{L}^{-1}(2.2$ $\mathrm{mg} \mathrm{m}^{-2}$ ) with manure removal to $2.9 \mathrm{mg} \mathrm{L}^{-1}$ (5.5 $\mathrm{mg}$ $\mathrm{m}^{-2}$ ) with manure accumulation. The Single treatment had the lowest TP concentrations in both experiments.

\section{Discussion}

\subsection{Measurements from All Seasons}

Except for incidental events, the concentrations of pollutants in fluids from all test areas were low and most were attributable to low animal density and inconsistent manure accumulation [3, 6]. However, part was attributable to absence of rainfall in the first season, leading to peak values of TAN, nitrate, nitrite and TS in the first rainstorm. Because of the teaching activities at Flyinge Horse Depot, manure was never allowed to accumulate for longer than a week at a time. An additional effect was that new material was used in the paddock pad areas and any accumulation of nutrients had to start from zero. All concentrations of nitrogen nutrients, TP and TS values in fluids peaked during and shortly after the rainstorm, which could be expected after a long period of no rain. The TN and COD values were not affected by the rainstorm and were consistently low throughout the period, despite manure values being within the range given in Table 1. 
For the Single treatment, nitrate $\left(\mathrm{NO}_{3}-\mathrm{N}\right)$ concentrations peaked at $170-200 \mathrm{mg} \mathrm{L}^{-1}$ in paddock 2 , whereas in the other test areas the concentrations peaked at $10 \%$ of that value. As a result of dry periods between rain events during summer and early autumn, the nitrate values increased in both drain effluent and leachate. Apart from the peak values, the nitrate and nitrite concentration in all fluids managed to meet the Swedish drinking water norm [20] of $<20 \mathrm{mg} \mathrm{L}^{-1}$ nitrate and $<0.10 \mathrm{mg} \mathrm{L}^{-1}$ nitrite.

\subsection{Fluid Flow Rate}

The applied rainfall from the SR was in balance with the sum of runoff, drain and leachate fluid flows during the SR experiments. Due to the denser gravel material, the fluid flow rates generally decreased 100 -fold per $\mathrm{m}^{2}$ compared with coarse gravel [15]. Despite this, the flow rate through the test area profile increased by 30 -fold per $\mathrm{m}^{2}$ compared with the rate reported by Singh [16] and all runoff disappeared within 20 minutes. If a coarser porous surface had been used for runoff infiltration at the edge of the paddock, runoff could be expected to have disappeared faster, but no runoff problems were observed during the two-year study.

The treatment difference in leachate flow rate agreed with results reported in Ref. [15] for the corresponding Combined geotextile treatment, but at a much lower fluid flow level (98\%) in the present study. With low fluid flow rates, the average nitrogen seepage rate from both Combined and Single pads (0.1 $\mathrm{g} \mathrm{m}^{-2}$ and $0.4 \mathrm{~g} \mathrm{~m}^{-2}$ day $^{-1}$ in both experiments) was below the required norm of $0.6 \mathrm{~g} \mathrm{~m}^{-2}$ day $^{-1}$ for a sealed liner [21]. All runoff, drain and leachate fluids in the SR study also met the Swedish drinking water norm [20].

\subsection{Runoff}

In response to the horse manure, the infiltrated runoff values of TN, TAN and COD in the manure removal study were 54\%, $90 \%$ and $32 \%$ lower than reported by von Wachenfelt [15], which was surprising with respect to COD values for horse manure, while TP and $\mathrm{NO}_{3}-\mathrm{N}$ runoff were $31 \%$ and 84\% higher, respectively. The manure accumulation runoff values almost coincided with the removal values, apart from much lower $\mathrm{NO}_{3}-\mathrm{N}$, but with an increasing TP of $39 \%$ for the paddock runoff compared with runoff recorded by von Wachenfelt [15] and also a $19 \%$ increase in relation to manure removal.

The effect on TAN of the Combined and Single geotextile treatments could have been partly the result of the ammonium ion being retained by the gravel through cation exchange [22]. However, it was also partly due to the average $\mathrm{pH}$ of most surface waters being sufficiently low to convert all ammonia to ammonium ions [23].

\subsection{Drainage Effluent}

All drain parameters displayed a reduction trend with lower parameter values compared with runoff in both experiments, except for nitrate and nitrite. This trend was most obvious in the manure removal study, with an experimental effect found for TP, COD and TS. The mean drain TP concentrations were 12 and $17 \%$ higher in the manure removal and accumulation experiments, respectively, than in Ref. [15]. However, the Single geotextile treatment in the removal experiment resulted in a 59\% lower TP value in the present study in relation to manure accumulation and a 47\% lower TP value compared with Ref. [15]. For COD, there was a mean experimental reduction effect of $23 \%$, which was similar to Ref. [15] but at a $44 \%$ lower effluent concentration level. The mean experimental reduction in TS (13\%) was half that achieved by von Wachenfelt [15], although the effluent concentration with manure accumulation was similar in both studies.

Furthermore, there were stronger treatment effects compared with experimental effects for the significant drain effluent parameters in the present study 
compared with Ref. [15], which could probably be explained by different gravel particle size combinations together with geotextiles [24].

Treatment effects were found in TN and TS, with $48 \%$ and $20 \%$ lower values, respectively, in the removal experiment for the Single compared with the Gravel treatment. The parameter values were approx. $70 \%$ and $0 \%$, respectively, below the values recorded by von Wachenfelt [15]. For both TP and COD, the Combined and Single treatment effects resulted in lower parameter values than the Gravel treatment. For Single, that meant a $62 \%$ reduction in $\mathrm{P}$ and a $51 \%$ reduction in COD compared to the Gravel treatment, and a COD concentration of only $60 \%$ of that found by von Wachenfelt [15]. The Single treatment achieved the lowest drain fluid concentrations of all treatments, which also resulted in the overall lowest nutrient content per unit test area for drain fluid, except for nitrate and nitrite.

Although the observed effects of decreased $\mathrm{N}$ nutrients and the limited increase in nitrate and nitrite levels in drainage effluent are promising, the fact remains that urine was not included in the SR study. With urine included, the nitrogen levels would probably have increased. In contrast to the previous experiment [15], the Single treatment probably had a better oxidising effect for both $\mathrm{NO}_{3}-\mathrm{N}$ and $\mathrm{NO}_{2}-\mathrm{N}$, with higher $\mathrm{NO}_{3}-\mathrm{N}$ values in both experiments, although the differences were not significant.

Due to experimental design, including pre-wetting and water application after manure application, ammonia volatilisation could be neglected [23]. However, in real situations there would be potential for ammonia volatilisation, especially with manure accumulation, which was not measured in this experiment.

\subsection{Leachate}

The reduction in nutrient concentrations in leachate continued in all test areas and in both experiments, but not as rapidly as in the drainage effluent. Despite higher TP in horse manure, TP reached its lowest value for the Single treatment with manure removal, which was only slightly higher than the corresponding value reported by von Wachenfelt [15]. The only increasing value was nitrate, which was much higher in both treatments and experiments than reported by Singh [16] and von Wachenfelt [15]. Comparing paddock leachate with cattle leachate [15], despite the higher horse manure concentration, the paddock and cattle leachate concentrations were approximately similar for TN, TAN, COD and TS, with lower concentrations of $\mathrm{TN}$ and TAN, but higher concentrations of COD and TS.

The paddock leachate nutrient content per unit area largely followed the fluid concentrations, with a higher content with manure accumulation and vice versa, except for $\mathrm{NO}_{3}-\mathrm{N}$ and $\mathrm{NO}_{2}-\mathrm{N}$. With the lower flow rate in the Combined treatment, the concentration of all substances, but especially TS, was lower than in the Single treatment, as also found by von Wachenfelt [15]. The mean nutrient content per unit area in both experiments was in the same range as found by von Wachenfelt [15], but lower for all parameters except for $\mathrm{NO}_{3}-\mathrm{N}$ and $\mathrm{TS}$ with manure removal and $\mathrm{TN}$ and $\mathrm{NO}_{2}-\mathrm{N}$ with manure accumulation.

\subsection{Design Considerations}

In comparing the two treatments, Single had slightly lower but consistent fluid flows, lower drain fluid concentrations, with lower $\mathrm{P}$ values in both experiments, and lower $\mathrm{P}$ values in leachate fluid. Single had lower nutrient concentrations per unit test area in drain effluent, while Combined had lower concentrations in leachate fluid. Both treatment effluent fluids met the norm for sealed liners. However, installing the Single treatment is simpler as there is only one geotextile, while with Combined there are three geotextiles.

The rapid fluid transport through the construction profile is obtained by short fluid transport distances and drainage over the entire surface area. With respect 
to runoff infiltration rate, there could be a need for a coarse gravel strip [15] along the paddock periphery and a holding pond to protect large paddock areas from rainstorm flooding. The drainage effluent composition and concentrations from both treatments were in agreement with Ref. [15] and as such were suitable for constructed wetland treatment $[25,26]$.

During the study, some horses dug holes into the gravel construction. This could be discouraged by using gravel netting or pervious concrete tiles. The mass balance calculation performed to estimate nutrient losses from the treatments in the present rainfall study was similar to that reported by von Wachenfelt [15]. As a mass balance result, most of the $\mathrm{P}$ was probably contained in the surface gravel layer [2]. If this layer is renewed with regard to paddock horse density, the source of pollution could be reduced.

\section{Conclusions}

This study evaluated whether a geotextile-gravel construction in practice gives an acceptably stable paddock surface for horses, runoff control, reduction of nutrients in the fluids leaving the test area and sealing towards the underlying soil surface instead of a membrane. It also investigated whether regular manure removal has an effect on runoff and drainage effluent quality.

Two different combinations of non-woven and woven geotextile together with two gravel fractions (16 and $5 \mathrm{~mm}$ ) of $200 \mathrm{~mm}$ were exposed to precipitation and horse manure/urine for two years under two manure regimes (manure removal and manure accumulation). In a SR study, the test areas were also exposed to $50 \mathrm{~mm}$ precipitation for $30 \mathrm{~min}$ and $15 \mathrm{~kg}$ of horse manure under the two manure regimes. Runoff, drainage effluent and leachate flow were measured and sampled for both regimes.

The geotextile-gravel construction reduced runoff and drained the test area throughout the two-year period, confirming pad stability and a dry walking surface layer at a mean drain fluid flow of 3.65 $\mathrm{Lm}^{-2} \mathrm{~h}^{-1}$. Compared with previous studies, the concentrations of TN, TP, COD and TS in the drain effluent fluids in winter were low because of low horse density.

The SR study confirmed that a $200 \mathrm{~mm}$ geotextile-gravel bed construction met the requirements set, but there could be a need for a coarse gravel strip for runoff infiltration. A runoff treatment effect was found for TAN, with a lower value for the Combined and Single treatments compared with Gravel in both experiments. TN, TAN and COD concentrations were lower than in a previous study, while TP values were 31\% and 39\% higher with manure removal and accumulation, respectively.

The Single treatment, with manure removal, had a better overall reducing effect for pollutants in drain effluent, especially for TN, TP, COD and TS (5.2, 1.9, 156, $654 \mathrm{mg} \mathrm{L}^{-1}$ and 13, 4.8, 390, 1,626 $\mathrm{mg} \mathrm{m}^{-2}$ ), with a $47 \%$ lower TP value compared with previously reported values. The mean experimental reduction in TN, COD and TS was 20\%, 22\% and 13\%, respectively, with manure removal. For TP, the mean drain concentrations were 12 and $17 \%$ higher, respectively, in the two experiments compared with a previous study.

An experimental effect in leachate was found, with 48\% lower mean TP with manure removal compared with manure accumulation. The Combined geotextile treatment had an advantage in terms of lower leachate fluid flow, with an overall lower nutrient content per unit test area. Both treatments met the norm for sealed liners and the effluents were suitable for wetland treatment, but the Single treatment was the easiest and most economical to install. The experiment showed promising treatment results in reducing diffuse sources of pollution, but a longer test period is needed to obtain reliable data.

\section{Acknowledgements}


Financial support from the Swedish-Norwegian Foundation for Equine Research (H1147167) and Region Skåne Fund for Environmental studies (M026) is gratefully acknowledged. I would also like to thank Sune Hagström, Anders Slätteryd for paddock design, Magnus Nilsson and Ingvar Jonsson for help carrying out the experiments and Jan-Eric Englund for statistical advice.

\section{References}

[1] White, R. K. 1973. Stream Pollution from Cattle Feedlot Runoff. Ohio Water Resources Center Project, Report No. 393. Ohio State University, 32.

[2] Parvage, M. M., Kirchmann, H., Kynkäänniemi, P., and Ulèn, B. 2011. "Impact of Horse Grazing and Feeding on Phosphorus Concentrations in Soil and Drainage Water.” Soil Use and Management 27: 367-75.

[3] Airaksinen, S., Heiskanen, M. L., and Heinonen-Tanski, H. 2007. "Contamination of Surface Run-off Water and Soil in Two Horse Paddocks.” Bioresource Technology 98: 1762-6.

[4] Närvänen, A., Jansson, H., Uusi-Kämppä, J., Jansson, H., and Perälä, P. 2008. "Phosphorus Load from Equine Critical Source Areas and Its Reduction Using Ferric Sulphate.” Boreal Environment Research 13: 265-74.

[5] Uusi-Kämppä, J., Närvanen, A., Kaseva, J., and Jansson, H. 2012. "Phosphorus and Faecal Bacteria in Runoff from Horse Paddocks.” Agricultural Food and Science 21: 247-59.

[6] Keskinen, R., Nikama, J., Närvänen, A., Uusi-Kämppä, J., Särkijärvi, S., Myllimäki, M., and Saastamoinen, M. 2014. "Reducing Nutrient Runoff from Horse Paddocks by Removal of Dung." In Proceedings: Equi-meeting, Infrastructures Horses and Equestrian Facilities. Le Lion d'Angers, France, October 6th and 7th 2014.

[7] Caselles, J. M., Raul, M., Murcia, M. P., Espinosa, A. P., and Rufete, B. 2002. "Nutrient Value of Animal Manures in Front of Environmental Hazards.” Communications in Soil Science and Plant Analysis 33 (15): 3023-32.

[8] Parkyn, S., and Wilcock, R. 2004. "Impacts of Agricultural Land Use.” In Freshwaters of New Zealand, edited by Harding, J., Mosley, P., Pearson, C., and Sorrell, B. New Zealand: Caxton Press.

[9] European Horse Network. 2015. "The European Horse Industry in the European Regions Key Figures 2010.” Accessed March 15, 2012. http://www.europeanhorsenetwork.eu/horse-industry.

[10] European Commission. 2015. Water Framework Directive. Accessed March 15, 2012. http://ec.europa.eu/environment/pubs/pdf/factsheets/wate r-framework-directive.pdf.

[11] KY-NRCS. 1998. Heavy Use Area Protection. Kentucky Natural Resources Conservation Service, Lexington, KY Conservation Practice Standard, Code 561.

[12] Franze, C., Urick, L., Moreira, V. R., Sheffield, R. E., and LeBlanc, B. D. 2009. Soil Stabilization Options for Horse Owners. Louisiana State University Agricultural Center, 1-4.

[13] Barrington, S. F., El-Moueddeb, K., Jazestani, J., and Dussault, M. 1998. "The Clogging of Non-Woven Geotextiles with Cattle Manure Slurries.” Geosynthetics International 5 (3): 309-25.

[14] Moo-Young, H. K., and Tucker, W. R. 2002. "Evaluation of Vacuum Filtration Testing for Geotextile Tubes.” Geotextiles and Geomembranes 20: 191-212.

[15] von Wachenfelt, H. 2011. "Performance of Geotextile-Gravel Bed All-Weather Surfaces for Cattle.” Biosystems Engineering 108: 46-56.

[16] Singh, A., Bicudo, J. R., and Workman, S. R. 2008. "Runoff and Drainage Water Quality from Geotextile and Gravel Pads Used in Livestock Feeding and Loafing Areas.” Bioresource Technology 99: 3224-32.

[17] ISS. 2003. Swedish Standard: “SS 028113, SS 028101:1-92 mod, KLK 65:1, 232:5 NMKL 231991 SS1910, SS028150-2, SS-EN ISO11905-1/Kone, SS-EN 11732:2005/Kone, SS028133-2/Kone, SS-EN 26777/Kone, SS EN ISO6878:2005/TRAACS, Spectroquant SS 028113.” Swedish Standards Institute.

[18] Kemira, A. S. 2001. Håndbog for Landmaen. Fredericia, Danmark.

[19] SAS Institute Incorp. 2011. Base SAS ${ }^{\circledR} 9.3$ Procedures Guide. Cary, NC, SAS Institute Incorporated.

[20] SNFA. 2001. Drinking Water Norm, SLVFS 2001:30, Swedish National Food Agency, in Swedish, Livsmedelsverket, 2001.

[21] Barrington, S. F., Stilborn, R., and Moreno, R. G. 1995. "Organic Liners for the Sealing of Earthen Reservoirs." Bioresource Technology 52: 101-7.

[22] Hooda, P. S., Moynagh, M., Svoboda, I. F., Edwards, A. C., Anderson, H. A., and Sym, G. 2000. "Phosphorus Loss in Drainflow from Intensively Managed Grassland Soils.” Journal of Environmental Quality 28: 1235-42.

[23] Cooper, C. M. 1993. "Biological Effects of Agriculturally Derived Surface Water Pollutants on Aquatic Systems, a Review.” Journal of Environmental Quality 22: 402-8.

[24] Boutron, O., Gouy, V., Touze-Foltz, N., Benoit, P., Chovelon, J. M., and Margoum, C. 2009. "Geotextile Fibres Retention Properties to Prevent Surface Water Nonpoint Contamination by Pesticides in Agricultural Areas.” Geotextiles and Geomembranes 27: 254-61.

[25] von Wachenfelt, H. 2003. Treatment of Manure 
Contaminated Rainwater from Outdoor Yards in a Constructed Wetland (in Swedish with English summary). Special report 245, Department of Agricultural Biosystems and Technology, Swedish University of Agricultural Sciences, 95.
[26] Kynkäänniemi, P., Ulén, B., Torstensson, G., and Tonderski, K. S. 2013. "Phosphorous Retention in Newly Constructed Wetland Receiving Agricultural Tile Drainage Water.” Journal of Environmental Quality 42: 596-605. 